\title{
THE EFFECTS OF NUCLEOSIDES ON THE RESISTANCE OF NORMAL HUMAN ERYTHROCYTES TO OSMOTIC LYSIS 1, 2
}

\author{
BY ERNST R. JAFFÉ,` BERTRAM A. LOWY, GRACE A. VANDERHOFF, \\ PHILIP AISEN, 4 AND IRVING M. LONDON
}

\author{
(From the Departments of Medicine and Biochemistry, Albert Einstein College of Medicine and \\ the Bronx Muricipal Hospital Center, New York, N.Y.)
}

(Submitted for publication May 13, 1957; accepted June 17, 1957)

The investigations reported in this paper proceeded on the hypothesis that maintenance of the structural integrity of the human erythrocyte is dependent on continued production and utilization of energy by the cell. In an attempt to test this hypothesis the susceptibility of fresh human erythrocytes to osmotic lysis was studied in terms of the influence of various compounds that might serve as substrates for energy yielding reactions within the erythrocyte. Particular attention was paid to glucose (3) and purine nucleosides $(4,7)$ which have been shown to prolong the viability of stored erythrocytes and to retard their progressive lysis and diminished resistance to hypotonic solutions. It may be noted, however, that the effectiveness of the purine nucleosides in the preservation of erythrocytes has recently been questioned (8).

\section{MATERIALS AND METHODS}

Blood freshly drawn from normal adults was defibrinated and the erythrocytes were washed three times with about three volumes of isotonic sodium phosphate buffer ( $\mathrm{pH} 7.3$ to 7.4). Each washing was carried out with centrifugation in a Servall Refrigerated Angle Centrifuge for 10 minutes at $1,600 \mathrm{G}$ and at $4^{\circ} \mathrm{C}$. (SS-1 rotor). The phosphate buffer was prepared to contain 3.76 grams $\mathrm{NaH}_{2} \mathrm{PO}_{4} \cdot \mathrm{H}_{2} \mathrm{O}$ and 11.62 grams $\mathrm{Na}_{2} \mathrm{HPO}_{4}$ in distilled water in a final volume of one liter. A fifty per

1 This work has been presented in part at meetings of The American Society of Biological Chemists at Atlantic City, April, 1956 (1) and The International Society of Hematology at Boston, August, 1956 (2).

2 This work was supported by grants from the Office of Naval Research (Contract Nonr-1765 (00)), from the American Cancer Society on the recommendation of the Committee on Growth of the National Research Council, and from the Atomic Energy Commission (AT (30-1) 1855).

${ }^{8}$ Fellow of the National Foundation for Infantile Paralysis.

4 Fellow of the American Cancer Society on the recommendation of the Committee on Growth of the $\mathrm{Na}$ tional Research Council. cent suspension of the washed erythrocytes in isotonic sodium phosphate buffer was prepared, and two milliliters of this suspension were added to four milliliters of isotonic phosphate buffer containing the compound under study. This procedure resulted in a final 16.7 per cent suspension of erythrocytes. After thorough mixing, the suspensions were incubated in a waterbath at $37^{\circ} \mathrm{C}$. for two hours, unless otherwise noted. Following incubation, the supernatant solution was removed after centrifugation in an International Clinical Centrifuge (about 1,600 G) for five minutes and the erythrocytes were washed twice with isotonic phosphate buffer. The erythrocyte suspensions were then restored to the original volume of six milliliters with isotonic phosphate buffer. Aliquots $(0.2 \mathrm{ml}$.) of each suspension were added to two milliliter portions of $\mathrm{pH} 7.4$ phosphate buffer solutions of varying hypotonicity and to distilled water. After mixing, these suspensions were allowed to remain at room temperature for 40 to 50 minutes, and then were centrifuged for five minutes in an International Centrifuge, Model SBV, size 1, at 2,000 RPM (810 G). One milliliter of supernatant solution was removed, diluted with four milliliters of water, and the extent of lysis was calculated from the amount of hemoglobin liberated as measured by the optical density at $541 \mathrm{~m} \mu$ determined in a Beckman DU spectrophotometer.

In some experiments isotonic sodium chloride, 0.875 per cent, replaced the isotonic phosphate buffer. The freshly obtained erythrocytes were washed three times with isotonic sodium chloride and the preparation of the suspensions of erythrocytes, the incubation, and the postincubation washings were carried out in a manner identical with the one employed with isotonic phosphate buffer. The extent of hemolysis was determined 40 minutes after the addition of $0.2-\mathrm{ml}$. aliquots of each suspension of erythrocytes to two milliliters of sodium chloride solution of varying hypotonicity and to distilled water. In the experiments in which the effect of inorganic phosphate was studied isotonic sodium phosphate buffer ( $\mathrm{pH} 7.4$ ) was mixed with isotonic sodium chloride to yield the desired concentration of phosphate.

Determinations of $\mathrm{pH}$ were made with a Beckman Model $\mathrm{G}$ glass electrode $\mathrm{pH}$ meter.

The concentrations of nucleosides were determined spectrophotometrically (9).

In several experiments smears of the erythrocyte suspensions were prepared at different stages and stained with Wright's stain. No morphological differences be- 
tween treated and untreated cells were observed, nor were there significant variations in hematocrit values.

Most of the purines, nucleosides and related compounds were obtained commercially. The purity of the purines and purine-containing compounds was determined by ultra-violet spectrophotometry and paper chromatography in suitable solvent systems. The 2,6-diaminopurine riboside (2,6-diamino-9- $\beta$-D-ribofuranosyl purine) and the adenine glucoside (9- $\beta$-D-glucopyranosyl adenine) were prepared by the method previously described (10). Samples of purine riboside (9- $\beta$-D-ribofuranosyl purine), benzimidazole riboside ( $1-\beta-D$-ribofuranosyl benzimidazole), and 6-acetamido-9-tetraacetyl- $\beta$-D-glucopyranosyl purine were generously provided by Dr. George B. Brown. The Phenergan ( ${ }^{\circledR}$-(2'-dimethylamino- $2^{\prime}$ methyl)-ethylphenothiazine hydrochloride) was kindly supplied by Mr. Ambrose Hunsberger, Jr., of Wyeth Laboratories.

The special conditions of washing, incubation and osmotic lysis were chosen for the following reasons. No further increases in hemolysis were found to occur after exposure to hypotonic phosphate buffer solutions for 40 to 50 minutes at room temperature $\left(20\right.$ to $25^{\circ} \mathrm{C}$. $)$. Since no differences in extent of lysis were noted in 15.0 per cent, 16.7 per cent, or 18.4 per cent suspensions of erythrocytes, the 16.7 per cent suspension was chosen. To control the effects of variation in the $\mathrm{pH}$ of the erythrocyte suspensions on the extent of hemolysis in hypotonic solutions (11), the cells were washed in isotonic phosphate buffer, $\mathrm{pH} 7.3$ to 7.4 , after incubation. Despite variations in $\mathrm{pH}$ from 7.0 to 8.2 during incubation with isotonic phosphate buffers of different $\mathrm{pH}$, the effect on osmotic lysis of the $\mathrm{pH}$ alone could be eliminated by this post-incubation washing with $\mathrm{pH} 7.3$ to 7.4 isotonic phosphate buffer (Table I). All experiments, unless otherwise noted, were performed with this control of $\mathrm{pH}$, and with the length of exposure to hypotonic solution, and with the concentration of erythrocytes maintained constant.

\section{RESULTS AND DISCUSSION}

Of the various types of compounds studied, certain purine ribosides, on incubation with fresh normal human erythrocytes, were found to produce marked enhancement of resistance to osmotic lysis. The effective compounds were adenosine, guanosine, inosine, 2,6-diaminopurine riboside (2,6-diamino-9- $\beta$-D-ribofuranosyl purine) and xanthosine. Although incubation with adenosine or 2,6-diaminopurine riboside resulted in elevation of the $\mathrm{pH}$ of the suspension, washing the erythrocytes with isotonic sodium phosphate buffer $(\mathrm{pH}$ 7.3 to 7.4) brought all the suspensions to the same $\mathrm{pH}$ as the control suspension prior to their being added to the hypotonic phosphate buffer solutions. The results of a typical experiment are presented graphically in Figure 1. Xanthosine, inosine and adenosine increased the resistance of erythrocytes to osmotic lysis, whereas deoxyinosine had no effect. A minimal degree of protection resulted from incubation with ribose-5-phosphate and glucose. The deoxyribosides, ribose-5-phosphate, and glucose are discussed below.

The protective effect was maximal at concentrations of 6 and 10 micromoles of adenosine per milliliter of incubation suspension (Table II) and at about 8 micromoles of inosine per milliliter of incubation suspension (Table III). Because of the limited solubility of the other nucleosides, studies of their optimal concentration were not performed. Neither adenosine nor inosine had a significant effect on susceptibility to osmotic lysis when the two hour incubation was conducted at $4^{\circ} \mathrm{C}$. The

TABLE I

Effect of pH on extent of hemolysis in hypotonic phosphate buffer after incubation for two hours in isotonic phosphate buffer

\begin{tabular}{|c|c|c|c|c|c|c|c|c|}
\hline $\begin{array}{l}\text { pH of incubation buffer } \\
\text { pH of suspension after incubation } \\
\text { pH of washing buffer } \\
\text { pH of suspension after washing }\end{array}$ & $\begin{array}{l}7.0 \\
7.2 \\
7.0 \\
7.1\end{array}$ & $\begin{array}{l}7.0 \\
7.2 \\
7.4 \\
7.4\end{array}$ & $\begin{array}{l}7.4 \\
7.5 \\
7.4 \\
7.4\end{array}$ & $\begin{array}{l}7.4 \\
7.5 \\
7.4 \\
7.4\end{array}$ & $\begin{array}{l}7.8 \\
7.9 \\
7.8 \\
7.8\end{array}$ & $\begin{array}{l}7.8 \\
7.9 \\
7.4 \\
7.4\end{array}$ & $\begin{array}{l}8.2 \\
8.2 \\
8.2 \\
8.2\end{array}$ & $\begin{array}{l}8.2 \\
8.1 \\
7.4 \\
7.4\end{array}$ \\
\hline $\begin{array}{l}\text { Per cent of } \\
\text { isotonicity }\end{array}$ & \multicolumn{8}{|c|}{ Per cent hemolysis } \\
\hline $\begin{array}{l}46 \\
43 \\
40 \\
37 \\
34\end{array}$ & $\begin{array}{l}17 \\
57 \\
85 \\
95 \\
98\end{array}$ & $\begin{array}{r}5 \\
21 \\
63 \\
88 \\
94\end{array}$ & $\begin{array}{r}4 \\
22 \\
62 \\
87 \\
94\end{array}$ & $\begin{array}{l}4 \\
21 \\
62 \\
88 \\
96\end{array}$ & $\begin{array}{r}2 \\
6 \\
22 \\
63 \\
87\end{array}$ & $\begin{array}{r}5 \\
20 \\
60 \\
87 \\
95\end{array}$ & $\begin{array}{r}2 \\
5 \\
16 \\
44 \\
73\end{array}$ & $\begin{array}{r}6 \\
22 \\
60 \\
86 \\
95\end{array}$ \\
\hline
\end{tabular}

* After incubation, half of the suspensions of erythrocytes was washed twice and re-suspended in isotonic phosphate buffer of the same $\mathrm{pH}$ as that of the buffer in which they were incubated, whereas the other half was washed twice and re-suspended in isotonic phosphate buffer, $\mathrm{pH}$ 7.4. 


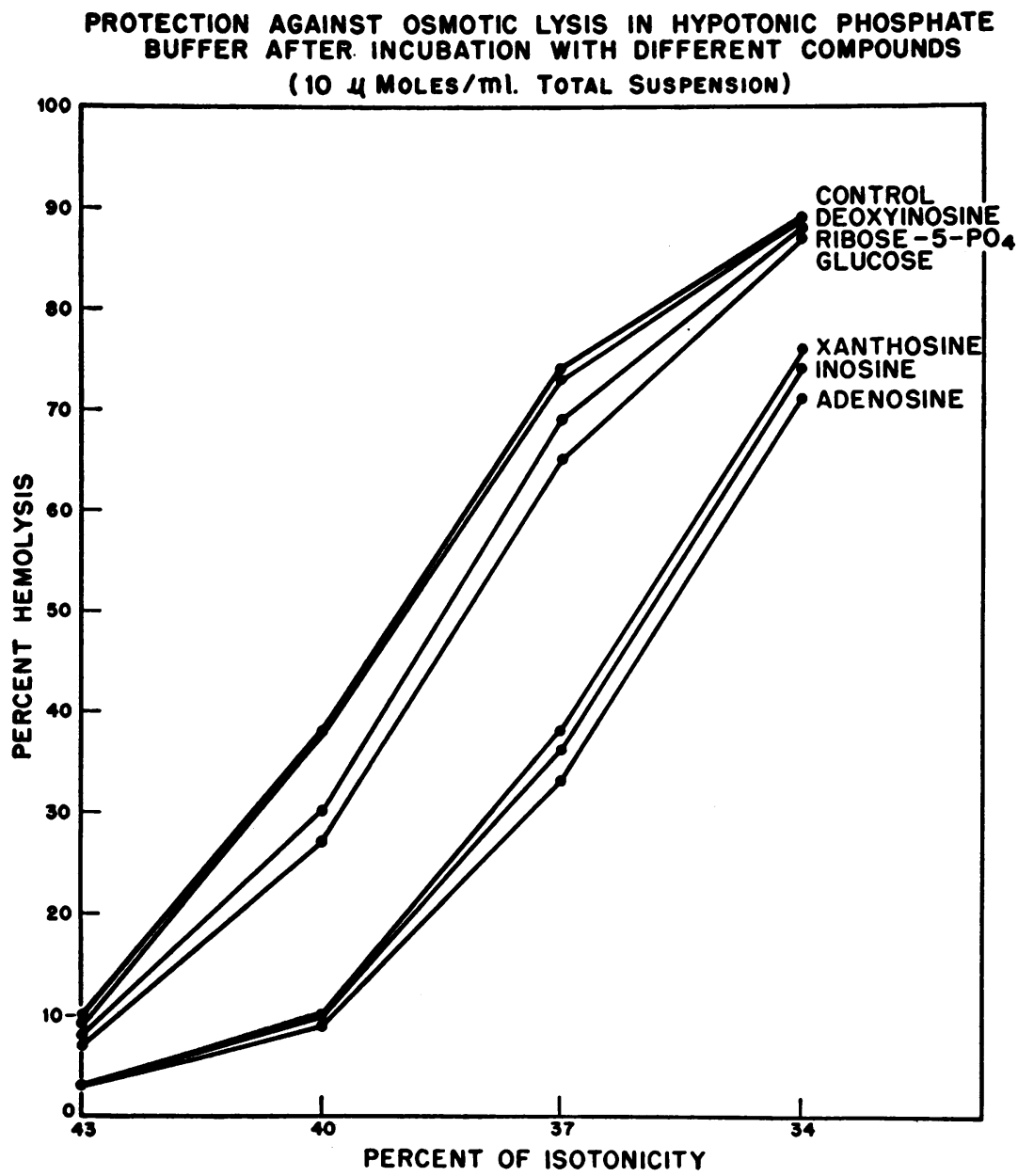

Fig. 1. Fresh Human Erythrocytes Incubated for Two Hours at $37^{\circ} \mathrm{C}$. in Isotonic Sodium Phosphate Buffer Alone or With 10 Micromoles Per Millititer of Various Compounds and Subjected to Osmotic Lysis in Phosphate Buffer Solutions of Varying Degrees of Hypotonicity

effect at $37^{\circ} \mathrm{C}$. was considerably greater than at room temperature (Table IV).

The protective effect of adenosine or inosine was apparent after one hour of incubation with these

TABLE II

Protection against osmotic lysis in hypotonic phosphate buffer after incubation for two hours with different concentrations of adenosine

\begin{tabular}{ccrcrrrrrr}
\hline & & \multicolumn{8}{c}{$\begin{array}{c}\text { Concentration of adenosine, } \\
\mu \mathrm{M} / \mathrm{ml} \text { suspension }\end{array}$} \\
\cline { 2 - 9 } $\begin{array}{c}\text { Per cent of } \\
\text { isotonicity }\end{array}$ & Control & 1.1 & 1.4 & 2.1 & 4.1 & 6.1 & 10.0 & 20.0 \\
\hline & & \multicolumn{6}{c}{ Per cent hemolysis } \\
\hline 100 & 2 & 3 & 2 & 1 & 2 & 1 & 2 & 2 \\
40 & 10 & 12 & 8 & 6 & 4 & 4 & 4 & 4 \\
37 & 30 & 28 & 24 & 19 & 12 & 10 & 10 & 9 \\
34 & 49 & 49 & 45 & 41 & 30 & 27 & 26 & 30 \\
31 & 67 & 67 & 66 & 62 & 57 & 52 & 51 & 54 \\
\hline
\end{tabular}

compounds at $37^{\circ} \mathrm{C}$. With longer periods of incubation, increased protection was observed. The effect of adenosine appeared less rapidly than that of inosine, but was somewhat more marked

TABLE III

Protection against osmotic lysis in hypotonic phosphate buffer after incubation for two hours with different concentrations of inosine

\begin{tabular}{|c|c|c|c|c|c|c|c|c|}
\hline \multirow{3}{*}{$\begin{array}{l}\text { Per cent of } \\
\text { isotonicity }\end{array}$} & \multirow{3}{*}{ Control } & \multicolumn{7}{|c|}{$\begin{array}{l}\text { Concentration of inosine, } \\
\mu \mathrm{M} / \mathrm{ml} \text {. suspension }\end{array}$} \\
\hline & & 1.0 & 1.9 & 4.1 & 5.8 & 7.8 & 9.9 & 21.5 \\
\hline & & \multicolumn{7}{|c|}{ Per cent hemolysis } \\
\hline $\begin{array}{r}100 \\
43 \\
40 \\
37 \\
34\end{array}$ & $\begin{array}{r}1 \\
9 \\
29 \\
68 \\
88\end{array}$ & $\begin{array}{r}1 \\
4 \\
21 \\
62 \\
87\end{array}$ & $\begin{array}{r}1 \\
2 \\
14 \\
47 \\
82\end{array}$ & $\begin{array}{r}2 \\
2 \\
6 \\
29 \\
72\end{array}$ & $\begin{array}{r}2 \\
1 \\
5 \\
24 \\
67\end{array}$ & $\begin{array}{r}1 \\
2 \\
5 \\
20 \\
68\end{array}$ & $\begin{array}{r}2 \\
3 \\
6 \\
25 \\
69\end{array}$ & $\begin{array}{r}2 \\
3 \\
9 \\
30 \\
71\end{array}$ \\
\hline
\end{tabular}


TABLE IV

Effect of incubation temperature on the protection against osmotic lysis in hypotonic phosphate buffer after incubation for two hours with adenosine or inosine *

\begin{tabular}{|c|c|c|c|c|c|c|c|c|c|}
\hline \multirow{3}{*}{$\begin{array}{l}\text { Per cent } \\
\text { of iso- } \\
\text { tonicity }\end{array}$} & \multicolumn{9}{|c|}{ Per cent hemolysis at incubation temperature } \\
\hline & \multicolumn{3}{|c|}{$4^{\circ} \mathrm{C}$. } & \multicolumn{3}{|c|}{$24^{\circ} \mathrm{C}$. } & \multicolumn{3}{|c|}{$37^{\circ} \mathrm{C}$. } \\
\hline & Control & Adenosine & Inosine & Control & Adenosine & Inosine & Control & Adenosine & Inosine \\
\hline $\begin{array}{l}46 \\
44 \\
42 \\
40 \\
38\end{array}$ & $\begin{array}{r}5 \\
15 \\
35 \\
62 \\
82\end{array}$ & $\begin{array}{r}5 \\
13 \\
31 \\
58 \\
80\end{array}$ & $\begin{array}{r}4 \\
12 \\
30 \\
56 \\
78\end{array}$ & $\begin{array}{r}7 \\
17 \\
39 \\
67 \\
86\end{array}$ & $\begin{array}{r}3 \\
10 \\
22 \\
49 \\
74\end{array}$ & $\begin{array}{r}4 \\
10 \\
23 \\
48 \\
73\end{array}$ & $\begin{array}{r}8 \\
21 \\
44 \\
71 \\
86\end{array}$ & $\begin{array}{r}3 \\
4 \\
10 \\
25 \\
49\end{array}$ & $\begin{array}{r}2 \\
5 \\
13 \\
31 \\
59\end{array}$ \\
\hline
\end{tabular}

* The concentration of adenosine was $\mathbf{1 0 . 0}$ and of inosine 9.9 micromoles per milliliter of incubation suspension.

after longer periods of incubation (two to four hours) (Figure 2).

In all studies in which osmotic resistance was enhanced there were considerable uptake and metabolism of the ribose moiety of the purine ribosides. Of the ribose metabolized, a major portion could be accounted for by increased lactate production. The details of these investigations are reported elsewhere (12).

When isotonic sodium chloride solution was substituted for the isotonic sodium phosphate buffer, incubation with adenosine, deoxyadenosine, guanosine, or 2,6-diaminopurine riboside at concentrations of two micromoles per milliliter increased resistance to osmotic lysis in hypotonic sodium chloride, whereas inosine and xanthosine were ineffective (Table V). However, except for guanosine, the compounds that exerted a protective effect in the sodium chloride system raised the postincubation $\mathrm{pH}$ to 7.8 , an alteration that could not be reversed completely by washing the erythrocytes with isotonic sodium chloride. When adenosine, deoxyadenosine, or 2,6-diaminopurine riboside was employed at a concentration of 10 micromoles per milliliter, the elevation of the $\mathrm{pH}$ was even more striking and attained values of 8.1 to 8.5. The $\mathrm{pH}$ of the control incubated in isotonic sodium chloride alone was 7.5 to 7.6 after incubation. Since elevation of the $\mathrm{pH}$ is known to inhibit hemolysis (11), the protective effects of

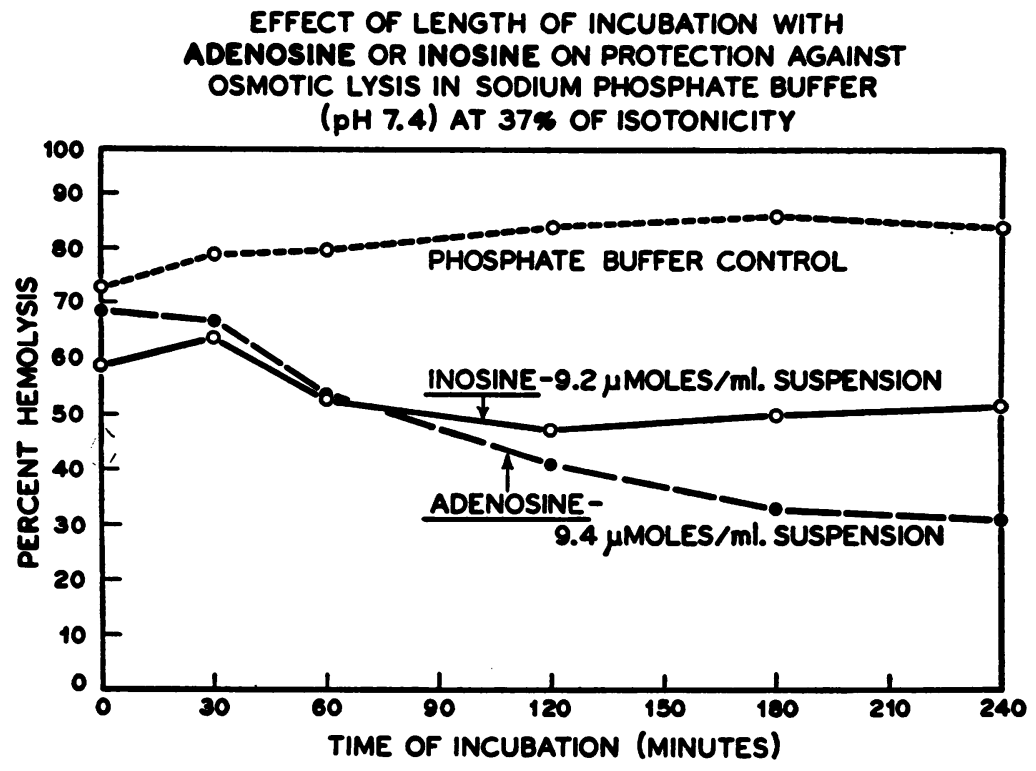

Fig. 2. Extent of Hemolysis of Fresh Human Erythrocytes in Phosphate Buffer at 37 Per Cent of Isotonicity After Incubation in Isotonic Sodium Phosphate Buffer Alone or with Adenosine or Inosine for DifFERENT LENGTHS OF TME AT $37^{\circ} \mathrm{C}$. 
TABLE V

Protection against osmotic lysis in hypotonic sodium chloride after incubation for two hours with purine nucleosides *

\begin{tabular}{|c|c|c|c|c|c|c|c|}
\hline & Contral & Adenoeine & $\begin{array}{l}\text { Deaxy- } \\
\text { adenodine }\end{array}$ & Guanosine & Inosine & 2,6-DAPR $\dagger$ & Xanthosine \\
\hline pH of suspension & 7.6 & 7.8 & 7.8 & 7.6 & 7.6 & 7.8 & 7.3 \\
\hline $\begin{array}{l}\text { pH of suspension } \\
\text { after washing }\end{array}$ & 7.5 & 7.6 & 7.6 & 7.4 & 7.4 & 7.7 & 7.3 \\
\hline $\begin{array}{l}\text { Per cent of } \\
\text { teotonicity }\end{array}$ & \multicolumn{7}{|c|}{ Per cent hemolysis } \\
\hline $\begin{array}{l}51 \\
49 \\
47 \\
45 \\
43\end{array}$ & $\begin{array}{r}4 \\
12 \\
31 \\
57 \\
80\end{array}$ & $\begin{array}{r}2 \\
4 \\
6 \\
16 \\
37\end{array}$ & $\begin{array}{r}2 \\
4 \\
9 \\
26 \\
49\end{array}$ & $\begin{array}{r}5 \\
7 \\
21 \\
39 \\
67\end{array}$ & $\begin{array}{r}3 \\
11 \\
33 \\
55 \\
78\end{array}$ & $\begin{array}{r}3 \\
8 \\
9 \\
31 \\
36\end{array}$ & $\begin{array}{r}9 \\
25 \\
43 \\
59 \\
80\end{array}$ \\
\hline
\end{tabular}

* Concentration of compounds was two micromoles per milliliter of incubation suspension.

† 2,6-diaminopurine riboside.

adenosine, deoxyadenosine and 2,6-diaminopurine riboside in the sodium chloride medium might be the result of the change in $\mathrm{pH}$ alone. Inosine, ineffective in the sodium chloride medium whose $\mathrm{pH}$ it did not alter, became effective on the addition of as little as 18 micromoles of inorganic phosphate per milliliter of incubation suspension (Table VI). These latter observations are compatible with the finding that erythrocyte nucleoside phosphorylase requires phosphate or arsenate for its action $(13,14)$.

The effect of guanosine in enhancing osmotic resistance of erythrocytes in a sodium chloride medium without added phosphate is not readily explained. Incubation with guanosine did not raise the $\mathrm{pH}$ above that of the control. Since phosphate or arsenate is required for activity of the erythrocyte nucleoside phosphorylase (13), the reason for the effectiveness of guanosine in this system without added phosphate is obscure.

In order to investigate the mechanism by which the purine nucleosides exert their effects on the susceptibility of human erythrocytes to osmotic stress, many related compounds were studied. When the nucleotides listed in Table VII (adenosine monophosphates, adenosine diphosphate, adenosine triphosphate, inosine- $5^{\prime}$-phosphate) were employed, there was no enhanced protection against osmotic lysis. When the purine portion of the effective compounds was replaced by another group, the protective effect was lost. The pyrimidine ribosides (cytidine, uridine) and benzimidazole riboside (1- $\beta$-D-ribofuranosyl benzimidazole) were ineffective. A change in the sugar moiety also resulted in loss of the protective effect. Incubation with purine or pyrimidine deoxy-

TABLE VI

Effect of inorganic phosphate on protection against osmotic lysis in hypotonic sodium chloride after incubation for two hours with inosine *

\begin{tabular}{|c|c|c|c|c|c|c|}
\hline & Control & Inosine & $9 \mu \mathrm{M} / m \mathrm{~m}_{\mathrm{S}} \mathrm{PO}$ & $\begin{array}{l}9 \text { mM/ml. PO. } \\
\text { +inosine }\end{array}$ & $18 \mu M / m l$. PO & $\begin{array}{c}18 \text { mM/ml. PO. } \\
\text { +inosine }\end{array}$ \\
\hline $\begin{array}{l}\text { pH of suspension } \\
\text { after washing }\end{array}$ & 7.7 & 7.7 & 7.7 & 7.6 & 7.6 & 7.6 \\
\hline $\begin{array}{l}\text { Per cent of } \\
\text { ieotonicity }\end{array}$ & \multicolumn{6}{|c|}{ Per cent hemolysis } \\
\hline $\begin{array}{r}100 \\
49 \\
46 \\
43 \\
40\end{array}$ & $\begin{array}{r}2 \\
9 \\
41 \\
79 \\
91\end{array}$ & $\begin{array}{r}1 \\
12 \\
44 \\
76 \\
91\end{array}$ & $\begin{array}{r}1 \\
22 \\
70 \\
85 \\
91\end{array}$ & $\begin{array}{r}2 \\
8 \\
42 \\
81 \\
89\end{array}$ & $\begin{array}{l}1 \\
23 \\
64 \\
74 \\
91\end{array}$ & $\begin{array}{r}1 \\
3 \\
22 \\
75 \\
86\end{array}$ \\
\hline
\end{tabular}

* Concentration of inosine was eight micromoles per milliliter of incubation suspension. 
TABLE VI

Compounds ineffective in enhancing resistance to osmotic lysis in hypotonic $p H 7.3$ to 7.4 sodium phosphate buffer

\begin{tabular}{|c|c|c|c|c|c|}
\hline Compound & Micromoles* & Compound & Micromoles* & Compound & Micromoles* \\
\hline $\begin{array}{l}\text { Nucleotides } \\
\text { Adenosine-2'-phosphate } \\
\text { Adenosine-3'-phosphate } \\
\text { Adenosine-5'-phosphate } \\
\text { Adenosine diphosphate } \\
\text { Adenosine triphosphate } \\
\text { Inosinic acid }\end{array}$ & $\begin{array}{l}10 \\
10 \\
10 \\
10 \\
10 \\
10\end{array}$ & $\begin{array}{l}\text { Purines } \\
\text { Adenine } \\
\text { Hypoxanthine } \\
\text { 2,6-diaminopurine } \\
\text { Intermediates of carbo- } \\
\text { hydrate metabolism }\end{array}$ & $\begin{array}{r}2,4 \\
2 \\
6\end{array}$ & $\begin{array}{l}\text { Tricarboxylic acid } \\
\text { cycle compounds } \\
\text { Oxaloacetic acid } \\
\text { Succinic acid } \\
\text { Fumaric acid } \\
\text { Malic acid } \\
\text { Citric acid }\end{array}$ & $\begin{array}{l}10 \\
10 \\
10 \\
10 \\
10\end{array}$ \\
\hline $\begin{array}{l}\text { Pyrimidine ribosides } \\
\text { Cytidine } \\
\text { Uridine }\end{array}$ & $\begin{array}{l}10 \\
10\end{array}$ & $\begin{array}{l}\text { Fructose } \\
\text { Galactose } \\
\text { Glucono-lactone }\end{array}$ & $\begin{array}{r}10,20,50 \\
10 \\
10\end{array}$ & $\begin{array}{l}\text { Miscellaneous compounds } \\
\text { Glycine } \\
\text { Methionine }\end{array}$ & 10 \\
\hline $\begin{array}{l}\text { Purine deoxyribosides } \\
\text { Deoxyadenosine } \\
\text { Deoxyinosine }\end{array}$ & $\begin{array}{l}2,10 \\
2,10\end{array}$ & $\begin{array}{l}\text { Ribose } \\
\text { Deoxyribose } \\
\text { Glycolic acid }\end{array}$ & $\begin{array}{r}4,10 \\
10 \\
10 \\
10\end{array}$ & $\begin{array}{l}\text { Cysteine } \\
\text { Glutamic acid } \\
\text { Aspartic acid }\end{array}$ & $\begin{array}{l}10 \\
10 \\
10\end{array}$ \\
\hline Deoxyguanosine & & $\begin{array}{l}\text { Sodium pyruvate } \\
\text { Sodium lactate }\end{array}$ & 10,20 & $\begin{array}{l}\text { \&-aminolevulinic acid } \\
\text { Glutathione }\end{array}$ & $\begin{array}{l}10 \\
10\end{array}$ \\
\hline $\begin{array}{l}\text { Pyrimidine deoxyribosides } \\
\text { Thymidine } \\
\text { Deoxycytidine }\end{array}$ & $\begin{array}{l}10 \\
10\end{array}$ & $\begin{array}{l}\text { Glucose-1-phosphate } \\
\text { Glucose-6-phosphate } \\
\text { Fructose-1,6-diphosphate }\end{array}$ & $\begin{array}{l}10 \\
10 \\
10\end{array}$ & $\begin{array}{l}\text { Nicotinamide } \\
\text { Oxythiamine }\end{array}$ & $\begin{array}{r}10 \\
1\end{array}$ \\
\hline $\begin{array}{l}\text { Related compounds } \\
\text { Benzimidazole riboside } \\
\text { Adenine glucoside } \\
\text { Purine riboside }\end{array}$ & $\begin{array}{r}6 \\
10 \\
10\end{array}$ & $\begin{array}{l}\text { 3-phosphoglyceric acid } \\
\text { 2,3-diphosphoglycerate }\end{array}$ & $\begin{array}{r}10 \\
6\end{array}$ & $\begin{array}{l}\text { Promethazine } \\
\text { Sodium acetate } \\
\text { Sodium chloride }\end{array}$ & $\begin{array}{r}0.16,0.4 \\
10,20,30 \\
10\end{array}$ \\
\hline
\end{tabular}

* Concentration in micromoles per milliliter of incubation suspension.

ribosides (deoxyadenosine, deoxyinosine, deoxyguanosine, thymidine, deoxycytidine) or adenine glucoside (9- $\beta$-D-glucopyranosyl adenine) failed to enhance resistance to osmotic lysis. The specificity of the phenomenon of protection against osmotic lysis was further supported by the lack of effect observed with purine riboside ( $9-\beta$-D-ribofuranosyl purine) itself.

Experiments were conducted to evaluate the influence of the component parts of the purine nucleosides. The purines, adenine, hypoxanthine, or 2,6-diaminopurine, alone were unable to increase resistance to osmotic lysis. From Figure 3 it is apparent that a mixture of six micromoles per milliliter of 2,6-diaminopurine with six micromoles of ribose-5-phosphate did not produce the protective effect afforded by an equivalent amount of 2,6-diaminopurine riboside. Ribose-5-phosphate, rather than ribose-1-phosphate, was used because of the extreme lability of the latter and because the presence of phosphoribomutase in the human erythrocyte is inferred $(15,16)$. Mixtures of adenine or hypoxanthine and ribose-5-phosphate, even when the pentose phosphate was present in a concentration eleven to twenty-two times that of the purine, were also ineffective. Incubation of fresh human erythrocytes with a purine and ribose-5-phosphate resulted in no greater protective effect than the slight effect observed with ribose-5-phosphate alone. The effect of a purine riboside plus ribose-5-phosphate plus a purine was no greater than that of a purine riboside plus ribose-5-phosphate alone. These findings indicate that there was little or no formation of nucleosides from added purine plus ribose-5-phosphate in the system used in these experiments.

With ribose-5-phosphate at concentrations ranging from 9 to 90 micromoles per milliliter of incubation suspension slight but increasing protective effects were noted. But even at 90 micromoles per milliliter, the protective effect of ribose5-phosphate was considerably smaller than that observed with 10 micromoles of an effective purine riboside (Table VIII). This limited effect may reflect the relative impermeability of the erythrocyte to the phosphorylated pentose. Ribose-5-phosphate has been shown to be as effective as adenosine in generating organic phosphate esters in hemolysates (17), but it is ineffective in intact erythrocytes (18).

The effects of various intermediates of carbohydrate metabolism were studied. Glucose provided a moderate degree of protection against osmotic lysis. This effect was independent of the 
concentration in a range of 5 to 100 micromoles per milliliter, perhaps as a result of the limited ability of the erythrocyte to utilize this sugar in vitro (Table IX). A disaccharide (sucrose), other hexoses (fructose, galactose, glucono-lactone), pentoses (ribose, deoxyribose), glycolic acid, sodium pyruvate, and sodium lactate were unable to enhance resistance to osmotic stress in the concentrations employed (Table VII). The phosphorylated intermediates of carbohydrate metabolism listed in Table VII were also ineffective, probably as a result of impermeability of the erythrocyte to phosphorylated sugars. Although the mature mammalian erythrocyte does not possess an intact tricarboxylic acid cycle, several of the enzymes of this cycle are known to be pres- ent (19). However, compounds of the cycle (citric, fumaric, malic, oxaloacetic and succinic acids) were unable to increase osmotic resistance.

A number of metabolites or agents unrelated in structure to purine ribosides were also studied. Several amino acids (aspartic acid, cysteine, glutamic acid, glycine, methionine), nicotinamide, glutathione, delta-aminolevulinic acid, sodium acetate and sodium chloride did not enhance resistance to osmotic lysis. Phenergan ${ }^{\circledR}$, reported by Schales to inhibit the progressive increase in osmotic fragility observed in whole blood stored with acid citrate-dextrose solution (20), was ineffective in the system used in these studies.

These experiments on freshly drawn human erythrocytes as well as the studies on stored
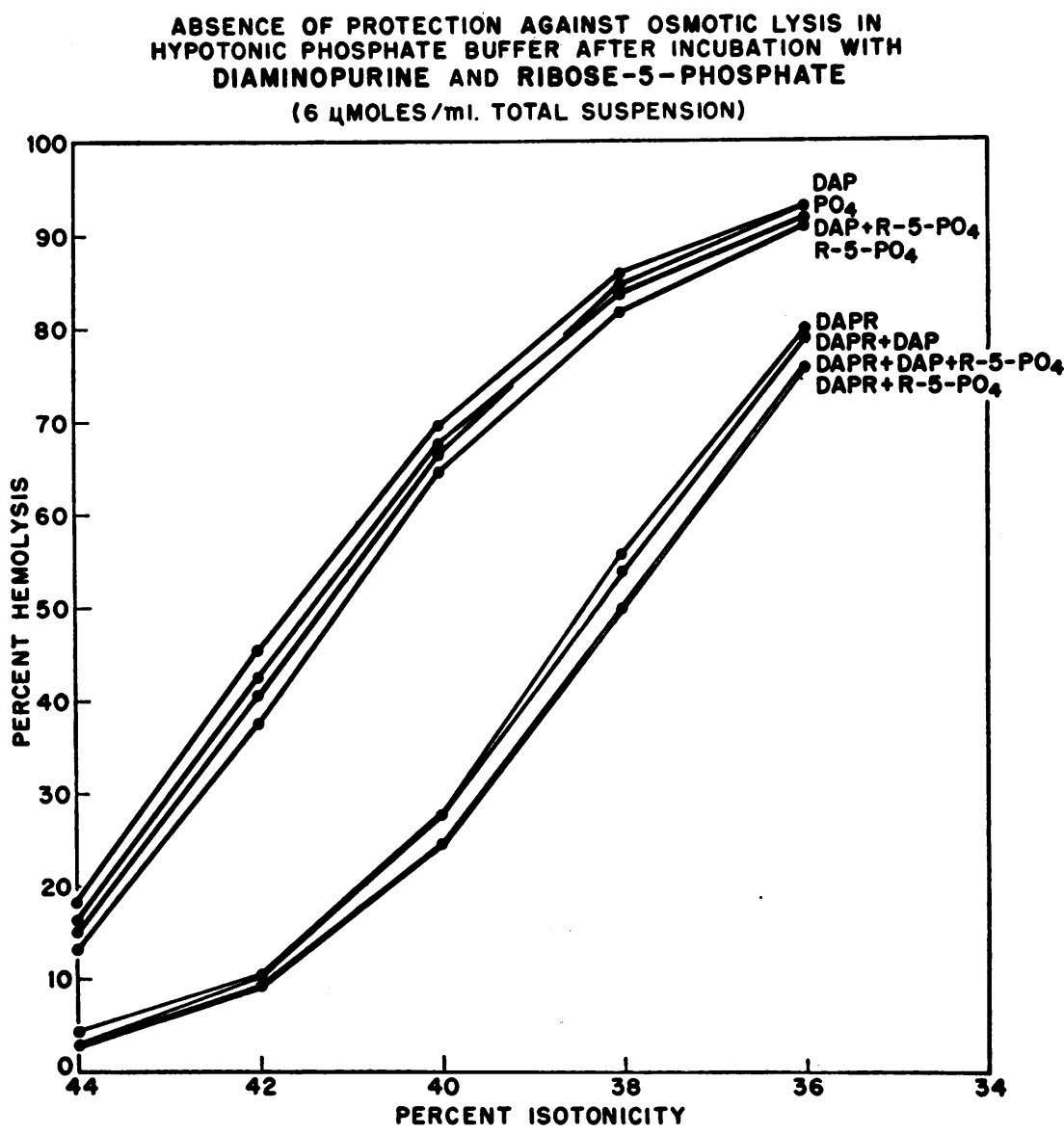

Fig. 3. Extent of Hemolysis of Fresh Human Erythrocytes in Hypotonic Sodiux Phosphate Buftgr After Two Hours. Incubation at $37^{\circ} \mathrm{C}$. In Isotonic Phosphate Butfer Alone or with 2,6-Diammopurine (DAP), Ribose-5-PhosPHATE (R-5-PO4), 2,6-DinMmopurine RIBOsme (DAPR), OR VARIOUS CoMbinations of Purnks, Purme Rmoside, and Pentose Phosphate 
TABLE VIII

Protection against osmotic lysis in hypotonic phosphate buffer after incubation for two hours with different concentrations of ribose-5-phosphate

\begin{tabular}{|c|c|c|c|c|c|c|c|c|}
\hline \multirow[b]{2}{*}{$\begin{array}{l}\text { Per cent of } \\
\text { isotonicity }\end{array}$} & \multirow[b]{2}{*}{ Control } & \multirow[b]{2}{*}{ Inosine* } & \multicolumn{6}{|c|}{$\begin{array}{c}\text { Concentration of ribose-5-PO } \\
\mu \mathrm{M} / \mathrm{ml} \text {. suspension }\end{array}$} \\
\hline & & & \multicolumn{6}{|c|}{ Per cent hemolysis } \\
\hline $\begin{array}{l}44 \\
42 \\
40 \\
38 \\
36\end{array}$ & $\begin{array}{l}11 \\
34 \\
61 \\
80 \\
90\end{array}$ & $\begin{array}{r}4 \\
8 \\
21 \\
46 \\
74\end{array}$ & $\begin{array}{l}11 \\
32 \\
60 \\
84 \\
92\end{array}$ & $\begin{array}{r}9 \\
28 \\
55 \\
80 \\
92\end{array}$ & $\begin{array}{r}8 \\
27 \\
54 \\
78 \\
92\end{array}$ & $\begin{array}{r}7 \\
21 \\
47 \\
74 \\
90\end{array}$ & $\begin{array}{r}6 \\
20 \\
44 \\
73 \\
90\end{array}$ & $\begin{array}{r}6 \\
18 \\
42 \\
70 \\
88\end{array}$ \\
\hline
\end{tabular}

* Concentration of inosine was 10 micromoles per milliliter of incubation suspension.

erythrocytes (4, 21-24) demonstrate that purine ribosides are an effective vehicle for introduction of ribose phosphate into the human erythrocyte. In correlative studies (12) it was shown that the ribose phosphate which is taken up by the erythrocyte can be accounted for to a considerable extent by an increased production of lactic acid. The reaction sequence for adenosine involves an initial deamination to inosine by an adenosine deaminase present in the erythrocytes of man and other species $(23,25)$. Phosphorolytic cleavage of the resulting inosine by nucleoside phosphorylase yields hypoxanthine and ribose-1-phosphate. Ribose-1-phosphate probably enters the hexose monophosphate shunt via conversion to ribose-5phosphate by phosphoribomutase whose presence in human erythrocytes is strongly inferred (15, 16). The ribose-5-phosphate can then be metabolized via the hexose monophosphate shunt and the Embden-Meyerhof pathway to lactic acid.

The nucleoside phosphorylase of the erythrocyte appears to be specific for inosine or guanosine (13). The requirement of this enzyme for inorganic phosphate would explain the lack of increased resistance to osmotic lysis when erythrocytes were incubated with inosine in isotonic sodium chloride solution and the appearance of enhanced resistance when inorganic phosphate was added to the medium. The reactions involved in the utilization of xanthosine or 2,6-diaminopurine riboside are not yet known but probably entail amination and deamination, respectively.

The mechanism for transfer of ribose phosphate into the erythrocyte by means of purine ribosides has considerable specificity. One may speculate that an effective purine riboside must have a specific structure which enables it to permeate or to be bound to the cell membrane in such fashion that the deaminase or nucleoside phosphorylase can readily react with it. Once the ribose has been cleaved phosphorolytically from the purine, the purine, in large part and perhaps wholly, is released to the environment of the cell $(23,26)$.

The subsequent metabolism of the ribose phosphate to lactic acid requires that at least a major portion of the hexose-monophosphate shunt and the Embden-Meyerhof pathway be intact. To determine whether the mechanisms involved in the protective effects of the purine ribosides may decline with aging of the erythrocyte, as do some enzymatic activities (27), the relationship of the age of the erythrocyte in vivo and on in vitro storage to the effects of purine ribosides on osmotic resistance has been investigated (28). The results of these studies indicate that the enhancement of osmotic resistance by inosine is greater in young than in old erythrocytes of the rabbit which have aged in vivo. They show also that human erythrocytes, stored in acid-citrate-dextrose solution at $4^{\circ} \mathrm{C}$., have an increased osmotic resistance after incubation with inosine. This effect, however, declines progressively with prolonged storage.

The effectiveness of the purine ribosides in enhancing osmotic resistance of fresh erythrocytes as well as in prolonging survival of stored erythrocytes suggests that this system for the study of osmotic lysis may provide a useful technique for screening agents which may be effective in the preservation of blood.

It is tempting to speculate on the mechanisms

TABLE IX

Protection against osmotic lysis in hypotonic phosphate buffer after incubation for two hours with different concentrations of glucose

\begin{tabular}{cccccccc}
\hline \hline & & & \multicolumn{5}{c}{$\begin{array}{c}\text { Concentration of glucose, } \\
\mu \mathrm{M} / \mathrm{ml} \text {. suspension }\end{array}$} \\
\cline { 5 - 9 } $\begin{array}{c}\text { Per cent of } \\
\text { isotonicity }\end{array}$ & Control & Adenosine* & 5 & 10 & 25 & 50 & 100 \\
\hline 42 & & & & & Per cent hemolysis & \\
40 & 10 & 4 & 7 & 6 & 6 & 6 & 7 \\
38 & 59 & 6 & 17 & 16 & 17 & 16 & 19 \\
36 & 84 & 38 & 47 & 46 & 44 & 44 & 46 \\
34 & 93 & 69 & 91 & 91 & 91 & 90 & 92
\end{tabular}

* Concentration of adenosine was 10 micromoles per milliliter of incubation suspension. 
by which the purine ribosides enhance osmotic resistance. It is known that the purine ribosides can promote the production of organic phosphate esters $(4,21,24)$, the retention of potassium (29), and the extrusion of sodium (30) in human erythrocytes. Enhanced osmotic resistance may reflect changes in the hydration of the erythrocyte which may result from these changes in organic phosphates and in electrolytes. Additional work is required, however, to determine whether the enhanced osmotic resistance may be associated with an active transport of water or with primary changes in the permeability of the erythrocyte membrane which are reflected in the movements of the electrolytes.

\section{SUMMARY AND CONCLUSIONS}

The resistance of fresh, normal human erythrocytes to osmotic lysis can be enhanced by incubation with the purine ribosides, adenosine, guanosine, inosine, 2,6-diaminopurine riboside, or xanthosine in an isotonic sodium phosphate buffer at $\mathrm{pH} 7.3$ to 7.4. This effect was also observed, but to a much lesser extent, on incubation of erythrocytes with glucose or ribose-5-phosphate.

It is suggested that the metabolism of purine ribosides in vitro provides energy which may be utilized in maintenance of the structural integrity of the erythrocyte subjected to osmotic stress.

\section{REFERENCES}

1. Lowy, B. A., Jaffé, E. R., Vanderhoff, G. A., Aisen, P., and London, I. M., Effects of nucleosides on the resistance of normal human erythrocytes to osmotic lysis. Federation Proc., 1956, 15, 304.

2. Jaffé, E. R., Lowy, B. A., Vanderhoff, G. A., Aisen, P., and London, I. M., The role of nucleosides in the maintenance of the structural integrity of the normal human erythrocyte. Program, VIth International Congress of Hematology, Boston, 1956, p. 471.

3. Rapoport, S., Dimensional, osmotic, and chemical changes of erythrocytes in stored blood. I. Blood preserved in sodium citrate, neutral, and acid citrate-glucose (ACD) mixtures. J. Clin. Invest., 1947, 26, 591.

4. Gabrio, B. W., Donohue, D. M., and Finch, C. A., Erythrocyte preservation. V. Relationship between chemical changes and viability of stored blood treated with adenosine. J. Clin. Invest., 1955, 34, 1509.
5. Donohue, D. M., Finch, C. A., and Gabrio, B. W., Erythrocyte preservation. VI. The storage of blood with purine nucleosides. J. Clin. Invest., 1956, 35, 562.

6. Gabrio, B. W., Donohue, D. M., Huennekens, F. M., and Finch, C. A., Erythrocyte preservation. VII. Acid-citrate-dextrose-inosine (ACDI) as a preservative for blood during storage at $4^{\circ} \mathrm{C}$. J. Clin. Invest., 1956, 35, 657.

7. Prankerd, T. A. J., Revival of stored blood with guanosine and its successful transfusion. Lancet, 1956, 1, 469.

8. Lange, R. D., Escobar, M. R., and Crosby, W. H., In vitro and in vivo studies of acid-citrate-dextroseinosine (ACDI) as a blood preservative. J. Lab. \& Clin. Med., 1956, 48, 919.

9. Cohn, W. E., The separation of nucleic acid derivatives by chromatography on ion-exchange columns in The Nucleic Acids, E. Chargaff and J. N. Davidson, Eds. New York, Academic Press, Inc., 1955, Vol. I, p. 211.

10. Davoll, J., and Lowy, B. A., A new synthesis of purine nucleosides. The synthesis of adenosine, guanosine and 2,6-diamino-9- $\beta$-D-ribofuranosy1purine. J. Am. Chem. Soc., 1951, 73, 1650.

11. Parpart, A. K., Lorenz, P. B., Parpart, E. R., Gregg, J. R., and Chase, A. M., The osmotic resistance (fragility) of human red cells. J. Clin. Invest., 1947, 26, 636.

12. Lowy, B. A., Jaffé, E. R., Vanderhoff, G. A., Crook, L., and London, I. M., The metabolism of purine nucleosides by the human erythrocyte in vitro, Submitted for publication.

13. Huennekens, F. M., Nurk, E., and Gabrio, B. W., Erythrocyte metabolism. I. Purine nucleoside phosphorylase. J. Biol. Chem., 1956, 221, 971.

14. Sandberg, A. A., Lee, G. R., Cartwright, G. E., and Wintrobe, M. M., Purine nucleoside phosphorylase activity of blood. I. Erythrocytes. J. Clin. Invest., 1955, 34, 1823.

15. Dische, Z., Synthesis of hexosemono- and diphosphate from adenosine and ribose-5-phosphate in human blood in Phosphorus Metabolism, W. D. McElroy and B. Glass, Eds. Baltimore, The Johns Hopkins Press, 1951, Vol. I, p. 171.

16. Gabrio, B. W., Finch, C. A., and Huennekens, F. M., Erythrocyte preservation: A topic in molecular biochemistry. Blood, 1956, 11, 103.

17. Gabrio, B. W., and Huennekens, F. M., Nucleoside metabolism of stored erythrocyte. Federation Proc., 1955, 14, 217.

18. Gabrio, B. W., Hennessey, M., Thomasson, J., and Finch, C. A., Erythrocyte preservation. IV. In vitro reversibility of the storage lesion. J. Biol. Chem., 1955, 215, 357.

19. Denstedt, O. F., The enzymology of the erythrocyte in Blood Cells and Plasma Proteins, J. L. Tullis, Ed. New York, Academic Press, Inc., 1953, p. 223. 
20. Schales, O., Effect of additions to ACD blood on erythrocyte preservation. Proc. Soc. Exper. Biol. \& Med., 1953, 83, 593.

21. Prankerd, T. A. J., and Altman, K. I., A study of the metabolism of phosphorus in mammalian red cells. Biochem. J., 1954, 58, 622.

22. Rubinstein, D., Kashket, S., and Denstedt, O. F., Studies on the preservation of blood. IV. The influence of adenosine on the glycolytic activity of the erythrocyte during storage at $4^{\circ} \mathrm{C}$. Canad. J. Biochem. \& Physiol., 1956, 34, 61.

23. Rubinstein, D., and Denstedt, O. F., The metabolism of the erythrocyte. XIV. Metabolism of nucleosides by the erythrocyte. Canad. J. Biochem. \& Physiol., 1956, 34, 927.

24. Prankerd, T. A. J., Chemical changes in stored blood, with observations on the effects of adenosine. Biochem. J., 1956, 64, 209.

25. Schaedel, M. L., and Schlenk, F., Adenosine and adenosine deaminase. Texas Rep. Biol. \& Med., 1948, 6, 176.
26. Hennessey, M., Finch, C. A., and Gabrio, B. W., Erythrocyte preservation. VIII. Metabolic degradation of nucleosides in vitro and in vivo. $\mathrm{J}$. Clin. Invest., 1957, 36, 429.

27. Allison, A. C., and Burn, G. P., Enzyme activity as a function of age in the human erythrocyte. Brit. J. Haemat., 1955, 1, 291.

28. Jaffé, E. R., Vanderhoff, G. A., Lowy, B. A., and London, I. M., The effect of nucleosides on osmotic resistance of mammalian erythrocytes in relation to the age of the cells (abstract). J. Clin. Invest., 1957, 36, 903.

29. Hoffman, J. F., and Tosteson, D. C., Restitution of the potassium transport system in human erythrocyte ghosts. Abstracts, XXth International Physiological Congress, Brussels, Belgium, 1956, p. 429.

30. Harris, E. J., and Prankerd, T. A. J., The effect of adenosine on the movement of sodium between erythrocytes and the suspension medium. Biochem. J., 1955, 61, xix. 